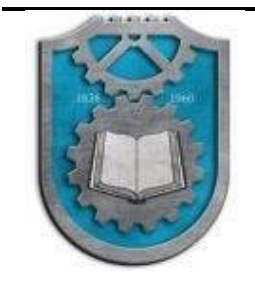

MOBILITY \& VEHICLE MECHANICS

DOI: $10.24874 / \mathrm{mvm} .2021 .47 .03 .03$

UDC: 622.7.092:621.43

\title{
STATIONARY TEST PLAN OPTIMISATION USING SLOW DYNAMIC SLOPE ENGINE SCREENING
}

Predrag Mrđa ${ }^{1}$, Nenad Miljić, $c^{2}$ Slobodan Popovic ${ }^{3}$, Marko Kitanovic ${ }^{4}$

Received in July 2020

Revised in September 2020

Accepted in February 2021

RESEARCH ARTICLE

\begin{abstract}
Requirements regarding high fuel efficiency, low pollutants and $\mathrm{CO}_{2}$ emission impact of the internal combustion (IC) engine results in high control calibration complexity. Modern IC engines are equipped with numerous electronically controlled subsystems, whose usage leads to almost exponential growth of stationary operating points that need to be evaluated and optimised. In that perspective, the methodology for fast preknowledge acquisition of examined system is presented through the application of Slow Dynamic Slope experiments - SDS. Continual slow change of a control parameter excites the system, in such a way, that allow obtaining of an approximately stationary operating regime, without the time-consuming operating point settling period. By analysing stationary-based approximation results of Slow Dynamic Slope experiments, conducted within the IC engine global operation domain (engine speed and load), certain zones could be identified. Within those zones, increased number of stationary tests is desirable in order to provide a more precise approximative model of observed engine output parameters. In this way, relatively fast dynamic SDS experiments could be used to optimise the stationarybased test plan leading to overall time savings dedicated to IC engine testing.
\end{abstract}

KEY WORDS: internal combustion engine, dynamic engine testing, slow dynamic slope, stationary based approximation, stationary test plan

(C) 2021 Published by University of Kragujevac, Faculty of Engineering

${ }^{1}$ Predrag Mrđa, M.Sc., Research assistant, University of Belgrade, Department of Internal Combustion Engines, Faculty of Mechanical Engineering, Kraljice Marije 16, 11120 Belgrade 35, Serbia, pmrdja@mas.bg.ac.rs (*Corresponding author)

${ }^{2}$ Nenad Miljić, PhD., assoc. prof., University of Belgrade, Department of Internal Combustion Engines, Faculty of Mechanical Engineering, Kraljice Marije 16, 11120 Belgrade 35, Serbia, nmiljic@mas.bg.ac.rs

${ }^{3}$ Slobodan Popović, PhD., assoc. prof., University of Belgrade, Department of Internal Combustion Engines, Faculty of Mechanical Engineering, Kraljice Marije 16, 11120 Belgrade 35, Serbia, spopovic@mas.bg.ac.rs

${ }^{4}$ Marko Kitanović, M.Sc., Research assistant, University of Belgrade, Department of Internal Combustion Engines, Faculty of Mechanical Engineering, Kraljice Marije 16, 11120 Belgrade 35, Serbia, $\underline{\text { mkitanovic@mas.bg.ac.rs }}$ 


\section{STACIONARNI TEST PLAN OPTIMIZACIJE PRAĆENJA KARAKTERISTIKE OPTEREĆENJA MOTORA SA MALIM KONSTANTNIM GRADIJENTOM PORASTA OPTEREĆENJA MOTORA}

REZIME: Zahtevi u vezi sa visokom efikasnošću goriva, niskim zagađivačima i uticajem emisije $\mathrm{CO}_{2}$ na motor sa unutrašnjim sagorevanjem (IC) rezultiraju velikom složenošću kontrole kalibracije. Savremeni IC motori opremljeni su brojnim elektronski kontrolisanim podsistemima, čija upotreba dovodi do gotovo eksponencijalnog rasta stacionarnih radnih tačaka koje je potrebno proceniti i optimizovati. U toj perspektivi, metodologija za brzo sticanje predznanja ispitivanog sistema predstavljena je primenom eksperimenata sa malim konstantnim gradijentom porata opterećenja (SDS). Kontinualna spora promena upravljajućeg parametra pobuđuje sistem tako da se dobija približno stacionaran režim rada, bez dugotrajnog perioda formiranja radne tačke. Analizom rezultata približno stacionarnog eksperimenata sa malim konstantnim gradijentom, sprovedenih u uobičajenom radnom režimu rada motora IC (broj obrtaja motora i opterećenje), mogle bi se identifikovati određene zone. Unutar tih zona, poželjan je povećan broj stacionarnih ispitivanja kako bi se obezbedio precizniji približni model posmatranih parametara izlazne snage motora. Na ovaj način, relativno brzi dinamički SDS eksperimenti mogli bi se koristiti za optimizaciju plana stacionarnog ispitivanja što dovodi do ukupne uštede vremena neophodnog za testiranje IC motora.

KLJUČNE REČI: motor sa unutrašnjim sagorevanjem, dinamičko ispitivanje motora, mali konstantni gradijent porasta opterećenja, stacionarna aproksimacija, plan stacionarnog ispitivanja 


\title{
STATIONARY TEST PLAN OPTIMISATION USING SLOW DYNAMIC SLOPE ENGINE SCREENING
}

\author{
Predrag Mrđa, Nenad Miljić, Slobodan Popović, Marko Kitanović
}

\section{INTRODUCTION}

Dynamic testing of internal combustion (IC) engines has been applied in the world for decades in the process of control parameters calibration. Taking into consideration the share of battery electric vehicles (BEV) on the market and predictions related to propulsion systems of the future, IC engines will maintain the dominant portion [1,2] as the primary propulsion technology of civil and commercial transportation. Given that IC engines are, in most cases, used in dynamic operation conditions, research in this area is of great importance. The basic idea of the Slow Dynamic Slope (SDS) method is to obtain approximate values of stationary approximations of the observed measured values in a much faster way, compared to stationary engine testing. The differences of the stationary approximations obtained in this way, compared with the results of the stationary test is expected because the IC engine could be represented as an extremely nonlinear dynamic system, with elements of stochastic processes. Because of this reason, unlike dynamic, stationary tests are the most reliable source of information about the work cycle at each operating point of an IC engine or a propulsion system generally. Considering increasingly demanding limitations that are required for modern IC engines, especially in terms of fuel economy and exhaust gases composition, further complexity increase of the propulsion systems is certain. Complex drive systems are characterized by an extremely high number of control parameters combinations. Testing of all those combinations on the test bench in stationary conditions cannot be realized within a reasonable time, and the economic framework. In this sense, the proposed analysis of the results of the SDS method has a favourable effect on the reduction of the number of operating regimes at which it is necessary to test the IC engine, while maintaining the quality of the approximation.

\section{SLOW DYNAMIC SLOPE METHODS}

Numerous papers on the topic of IC engine testing and modelling as a complex nonlinear and dynamic system, confirm the real need of the industry for further research in this area $[3,4,5]$. Dynamic tests of IC engines, based on the method of the continual control parameter change by ramp function are relatively old [6], but with the development of IC engine test bench systems, the potential of those methods increases. In the paper [7] the results of the IC engine dynamic testing using the SDS method over the engine load parameter are presented. The load is varied continuously in the area of positive torque with short-term retention at the minimum and maximum absolute values of the control parameter. Also, paper [7] presents the results of two, relatively fast SDS cycles, with symmetrical slopes of the control parameter focusing on the response trace of the exhaust gas NOx content. In addition to monitoring the response of IC engine effective parameters in the global domain (speed and load), in [8] the SDS method was applied for the purpose of optimizing the ignition angle and distribution system parameters of an IC engine. In other words, quantities that are a function of global control variables are used as a sweep parameter. For such a research to be conducted, the test bench at AVL Research Centre was equipped with engine control unit (ECU) capable of performing controlled sweeps of engine control parameters. Particularly positive results in the field of application of SDS methodology were elaborated in the paper [9], which was created through the cooperation of 
the automotive industry - BMW and AVL. In that paper, special attention is given to the calibration of control parameters near the safe operation boundary, i.e. safe region for the tested engine and used measuring equipment. MAZDA, as one of the leading companies in terms of innovation in the global automotive industry, has also, in cooperation with AVL, conducted research in this field [10]. The optimization of diesel engine control in transient modes was analysed using a similar method and presented in the dissertation [11]. As part of this research, the author devoted himself to the analysis of very fast changes in fuel injection quantities, defined by slope functions in the time domain over the successive work cycles in order to study the system response in terms of effective torque and possible corrections and maintaining the desired mixture composition. HONDA engineers, through research [12], published the results of stationary approximation of particulate emissions of gasoline engine with direct injection using SDS methodology introducing dynamic control of the start of injection (SOI) parameter in the crank angle domain. Also, in that research, an SDS method with variable gradients within a single dynamic sweep was applied, in order to apply a smoother change within areas where higher particulate emissions are expected. The potential of SDS methodology has not been fully explored and further research is still being done to improve it. The latest researches are those conducted through the cooperation of the Department of Engines at the Faculty of Mechanical Engineering in Belgrade and AVL from 2015 [13].

By analysing the available literature and published research results, the advantages and disadvantages, as well as the assumptions that could be applied during engine testing, are clearly distinguished. The general idea of applying a dynamic test of an IC engine, with a relatively slow change of the control parameter, is that the results of such a test completely replace the results of the stationary examination in the domain of varied control parameter. Unfortunately, some IC engine operating processes have a distinct time constant, i.e. they react relatively slowly to the changes of the input parameter. Those values could be tested and evaluated in SDS way, but only with limited accuracy levels due to significant deviation from stationary test results. On the other hand, it can be shown that with the SDS method and with the usage of adequate measuring techniques, it is possible to form very precise stationary approximations. Additionally, if the observed engine parameter is characterized by a relatively fast dynamic response, the match with stationary experimentation is acceptable.

Within the framework of this paper, the main goal of applied SDS method, is implementation of preliminary steps for more effective definition of the stationary test plan. In doing so, the level of prior knowledge about the examined IC engine, or any other system under test, will increase rapidly utilising this type of dynamic test. In the publication [3] and in the previous research of the authors $[14,15]$, the theoretical foundations of the SDS mode of excitation are presented. Figure 1 shows the SDS excitation $u(t)$ and the response $y(t)$ of an arbitrary linear system. Also, the stationary characteristic of such a system, the dynamic response as a function of excitation and the middle line of the formed SDS trace are shown. The stationary characteristic can be interpreted as the response of a system with negligibly small time constant $\left(T_{1}=0\right)$. 

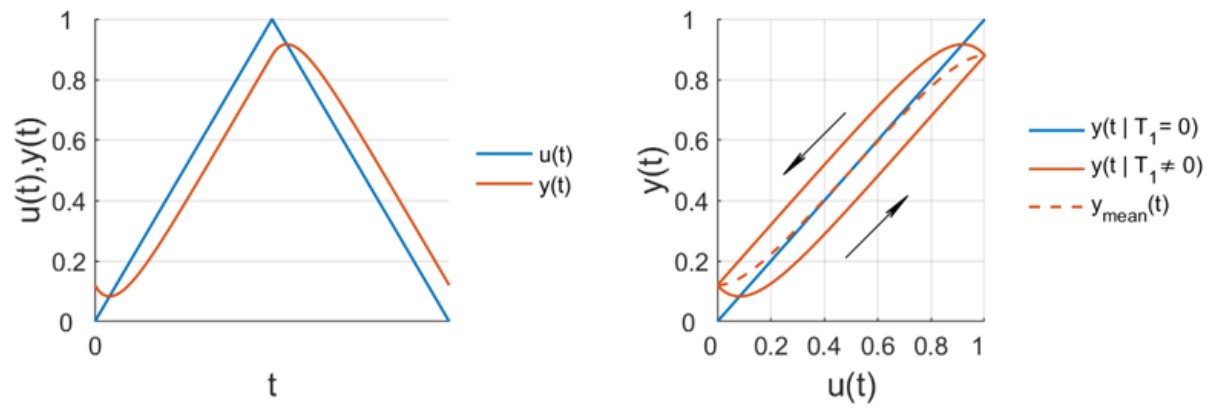

Figure 1 Example of excitation and the arbitrary first order linear system response by means of SDS test

It is noticed that in a relatively wide range of the input values, matching of stationary response and the midline of the SDS envelope is relatively good. In practice, the results are different and strongly depend on system dynamics and nonlinearity, but the analogy with the response analysis of a first-order linear system is evident. In that manner, an identical conclusion can be drawn when considering an example of a nonlinear system with first order dynamics. The example of nonlinear system is formed using simple Hammerstein-Wiener model and comparative analysis is shown in the Figure 2. SDS excitation and the system response are given in the time domain, alongside overlapped system stationary characteristics and the middle line of SDS trace.
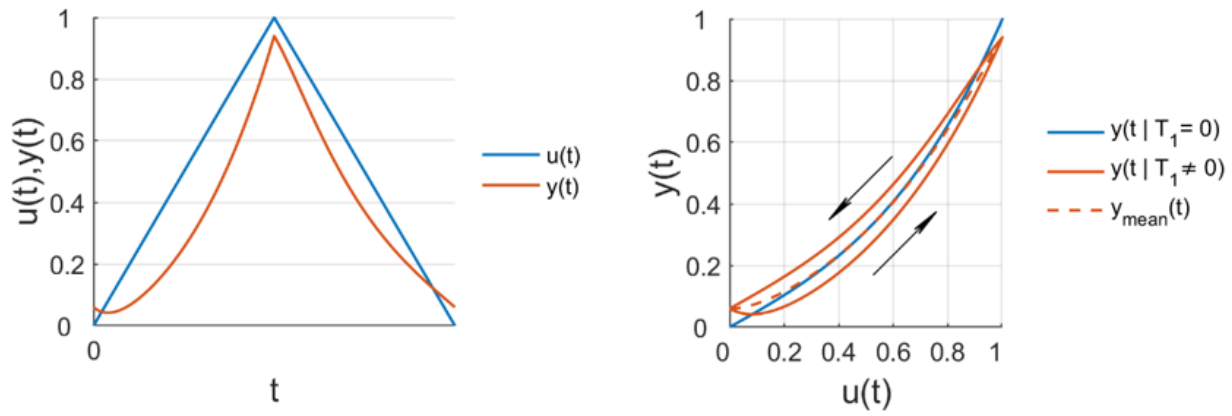

Figure 2 Example of excitation and the arbitrary first order nonlinear system response by means of SDS test

By analysing the deviations of the actual stationary characteristics and approximations obtained through the SDS experiment, the potential and benefits of the SDS method, as a way of IC engine testing method, could be identified. Relatively fast dynamic tests with a slow change of the control parameter can provide the collection of a large amount of information about the tested object in a very short time. How small the difference between the SDS results will be, comparing to the actual stationary values, depends on many factors, such as the dynamics of the observed process and the slope of the SDS excitation ramp. Of course, the excitation slope factor affects the duration of the dynamic experiment (i.e. the cost of the experiment), but this parameter is certainly a matter of compromise. 
In previous research by the authors $[14,15]$, a comparative analysis of the different slopes (and thus durations) of SDS ramps were given and the different ways of preparing the IC engine before the main part of the dynamic sweep were analysed. In these researches, the focus was on stationary and dynamic system preparation in terms of engine load variations during SDS experiment and for engine speed kept at constant level.

\section{ENGINE TEST BENCH SETUP}

Systems used for in-laboratory IC engine testing are very complex. The process of testing modern IC engines would be practically impossible without a certain level of system automation. Automated monitoring and display of measured values provides insight into the operating parameters of the used laboratory installation, with the possibility of checking limit values, such as the maximum allowable exhaust temperature or the allowable level of detonation in the cylinder, during adjusting phase of the operating point. In addition to the protection of the engine and measuring equipment, by monitoring other measured values, it is possible to detect malfunctions on the installation, in a timely manner, thus avoiding the need to repeat the measurement. Automated data collection into files has long been standard in engine testing. In this way, it is possible to calculate the statistical parameters of the measured quantities over an arbitrary population of data in terms of mean value, standard deviation, coefficient of variation and the like. If the test plan is extensive, which implies long-term testing, systems for automated experimentation without permanent operator supervision are applied. Automated IC engine testing plans are implemented using commercially available software AVL CAMEO [16]. The basic functionality of AVL PUMA Open software, in terms of communication between the AVL CAMEO software and the dyno controller, was implemented within the NI LabVIEW programming environment. AVL CAMEO software is an engineering tool that enables complete control of the test bench for engine testing, calibration of control parameters and formation of simple mathematical models of parameters that characterize the IC engine working process. Figure 3 shows the schematics of software and application units for automated adjustment of the operating point of the IC engine realized at the Department of Engines of the Faculty of Mechanical Engineering in Belgrade.

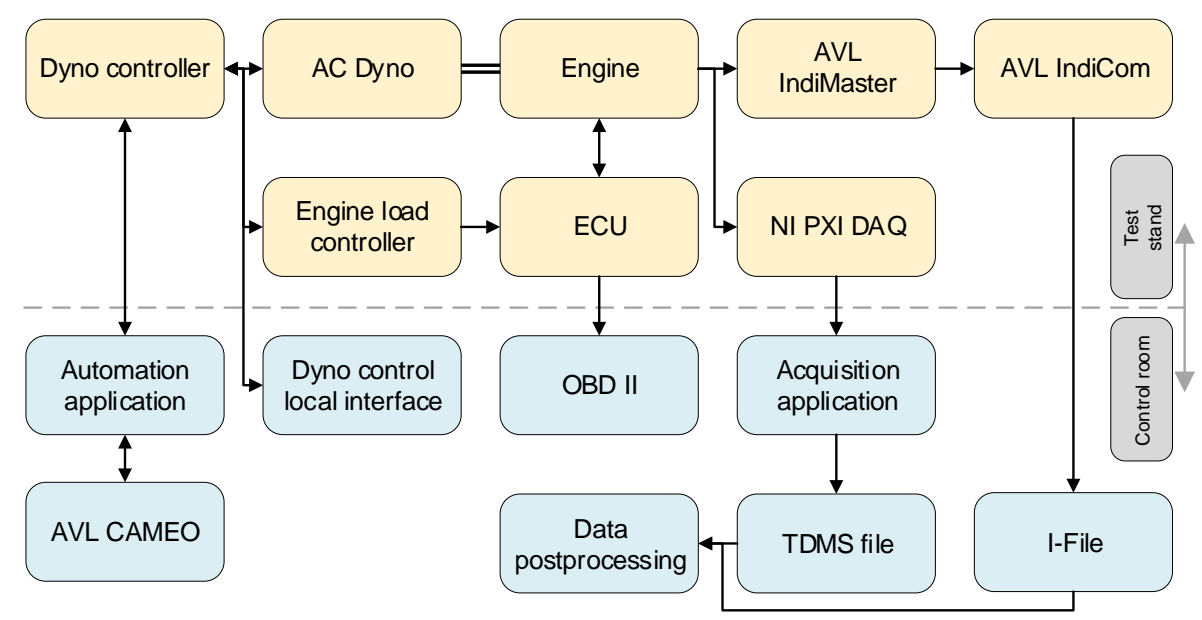

Figure 3 Engine test bench systems configuration 
The engine is connected to the dynamometer via a shaft mounted torque-meter. The brake controller parameters, as well as the ECU parameters, are accessed via a test automation application. Time domain data acquisition is based on the NI PXI hardware and LabView software. The AVL IndiMaster platform, AVL 3064Z01 encoder, AVL Micro IFEM 4P4G charge amplifiers with the corresponding AVL IndiCom software is used to indicate incylinder pressure values. Post-processing of time domain acquisition data (TDMS files) and engine indication data (IFiles) gives the final datasets for stationary and dynamic tests. The IC engine and the dynamometer basic features are shown in the Table 1.

Table 1 IC engine and dyno basic features

\begin{tabular}{|c|c|c|}
\hline \multirow{9}{*}{$\begin{array}{l}\stackrel{\Xi}{60} \\
\tilde{I} \\
\cup\end{array}$} & manufacturer & PSA group \\
\hline & type & DV4TD \\
\hline & fuel type & diesel \\
\hline & injection type & direct injection (HDI) \\
\hline & displacement & $1398 \mathrm{~cm} 3$ \\
\hline & piston bore / stroke & $73.7 \mathrm{~mm} / 82.0 \mathrm{~mm}$ \\
\hline & compression ratio & $18: 1$ \\
\hline & max. performance & 40 kW@4000 min-1, 130 Nm@1750 min-1 \\
\hline & turbocharger & BorgWarner KP35 (3K-BW), no intercooler \\
\hline
\end{tabular}

\begin{tabular}{|c|c|c|}
\hline \multirow{2}{*}{} & manufacturer & Rotronics \\
\cline { 2 - 3 } & type & Dynosens \\
\cline { 2 - 3 } & AC motor & SCHORCH LN8280M-A \\
\cline { 2 - 3 } & max. performance & $300 \mathrm{~kW} @ 9200$ min-1, 720 Nm@540-4200 min-1 \\
\cline { 2 - 3 } & max. rotational speed & 10000 min-1 \\
\cline { 2 - 3 } & & \\
\hline
\end{tabular}

\section{SDS TEST RESULTS INTERPRETATION}

As an example of the SDS test results analysis, the engine intake manifold pressure trace, at the section after of the compressor, was taken. In the following, this channel is marked as P_21. Figure 4 shows the envelope of the pressure trace during the SDS experiment at 1500 $\left[\mathrm{min}^{-1}\right]$ for different inclinations of the engine load, i.e. different durations of the SDS experiment for the desired load range (from $0[\mathrm{Nm}]$ to the maximal load of $115[\mathrm{Nm}]$ ). The 
results shown in this figure correspond to the setting of a dynamic test as a repeatable input parameter (load) oscillation. Also, a line corresponding to the P_21 stationary characteristic in these regimes is given. On the right-hand side of the Figure 4 the relative difference of the SDS test envelope middle line in comparison to the stationary values of the $\mathrm{P} \_21$ parameter is shown.The physicality of the working process and the characteristics of the measuring equipment in terms of its ability to react quickly enough on the control parameter changes lead to approximately equal values of the relative difference of the middle line of the SDS envelope in comparison to the stationary test. For the observed parameter, the largest output differences, in terms of SDS test duration, are observed at higher loads for a given engine speed. Numerical values in line label correspond to SDS duration, thus D120 means that effective part of SDS test lasted 120 seconds. Since it is a turbocharged engine, any delay of the temperature rise (and fall) in the exhaust system directly affects the rate of increase of the enthalpy of exhaust gases, and the amount of energy that will be transferred to the compressor unit depends on the energy of the exhaust gases, which further reflects on the values of the parameter P_21.
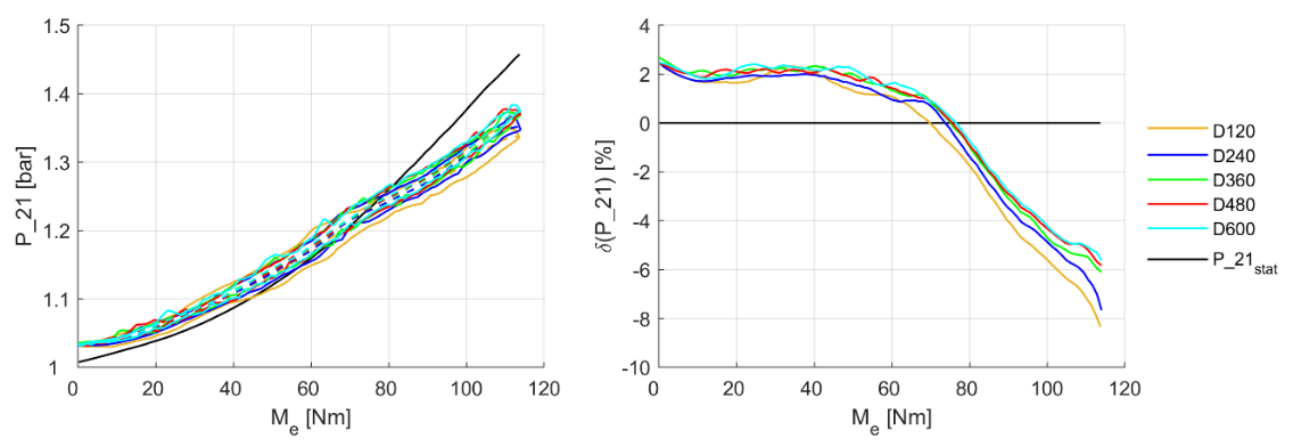

Figure 4 Intake manifold pressure traces $\left(P \_21\right)$ for various SDS test durations and SDS middle line relative differences in relation to stationary values $\left(P \_21_{\text {stat }}\right)$ at $1500\left[\mathrm{~min}^{-1}\right]$

The intake manifold absolute pressure $P_{-} 21$ is selected as an example because this parameter possess relatively fast dynamic response and a sufficiently large magnitude of change as a function of the independent control variables (engine speed and load). Figure 5 shows a stationary approximation of this parameter for the shortest SDS test duration. In the same figure, on the right-hand side, the relative difference of $\mathrm{P} \_21$ in comparison with the stationary data is shown. It is noticed that the deviation for the most part is about $\pm 2 \%$. It should not be forgotten that the universal diagram was recorded with four SDS sweeps (at engine speeds 1500, 2000, 2500 and 3000 [min-1]) and that each of them lasted 2 minutes. The data needed for the universal characteristics diagram in Figure 5 were obtained in approximately 10 minutes of engine testing. 

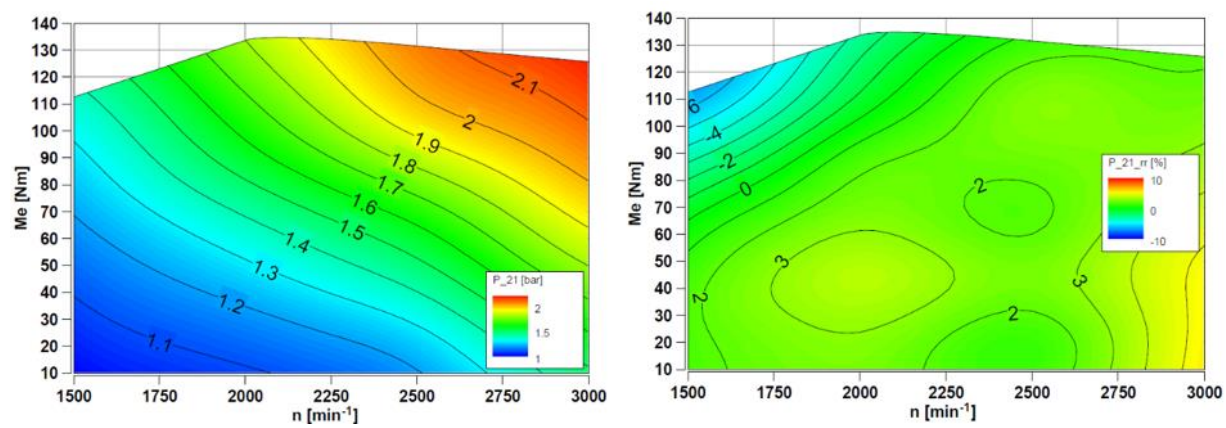

Figure 5 Intake manifold pressure P_21 universal characteristics obtained by SDS method, and relative diferencess od this paramater compared to stationary exsamination (P_21_rr)

\section{KEY STATIONARY TEST POINTS BASED ON SDS RESULTS}

If there is a nonlinear stationary characteristic that needs to be identified using experimental methods, the points of the stationary test-plan need to be distributed as uniformly as possible regarding the quality of used fitting model. It is also desirable that the test points be selected by one of the known quasi-random methods, such as Sobol or Halton sequences, so that the test-plan can be expanded if needed.

The correct selection of test-plan points is as important as the selection of appropriate mathematical model for approximations formation. For systems with distinct nonlinearity, it is desirable that a larger number of test points be positioned in the areas of higher absolute values of the second derivative of the observed nonlinearity [17], which for system with one input can be defined as:

$$
\nabla^{2} y(u)=\frac{\partial^{2}}{\partial u^{2}} \vec{e}_{u_{1}}
$$

For systems with two independent inputs, the combined value of output first derivative could be defined as:

$$
\nabla y\left(u_{1}, u_{2}\right)=\frac{\partial y}{\partial u_{1}} \vec{e}_{u_{1}}+\frac{\partial y}{\partial u_{2}} \vec{e}_{u_{2}}
$$

by determining the Euclidean distance, an argument is obtained for determining the second derivative:

$$
\nabla^{2} y\left(u_{1}, u_{2}\right)=\nabla\left\|\nabla y\left(u_{1}, u_{2}\right)\right\|=\frac{\partial^{2} y}{\partial u_{1}^{2}} \vec{e}_{u_{1}}+\frac{\partial^{2} y}{\partial u_{2}^{2}} \vec{e}_{u_{2}}
$$

By determining intensity of the observed function second derivative, finding the absolute value and normalization, the function that quantifies the areas for adding points on the whole domain of independent input variables $u_{-} 1$ and $u_{-} 2$ is obtained in form:

$$
F\left(u_{1}, u_{2}\right)=\operatorname{norm}\left(\operatorname{abs}\left(\left\|\nabla^{2} y\left(u_{1}, u_{2}\right)\right\|\right)\right)
$$

Figure 6 shows the values of such a function $\left(\mathrm{F}\left(\mathrm{u} \_1, \mathrm{u} \_2\right)\right)$, which quantifies the area for adding the test-plan points based on the analysis of the pressure values in the intake manifold (P_21) gathered during stationary engine examination. For simplification, this 
function will be named "condition function" in the following lines. In addition, Figure 6 shows submodels (boundaries and central positions) of the global LOLIMOT approximation model [18]. In this case, a relatively complex LOLIMOT model with 80 submodels was formed, because it enables a more precise comparison of IC engine global subregions. It is noticed that there is a certain coincidence between the areas of more intensive condition function values and the areas in which the multiple partitioning of the LOLIMOT model. In these areas, the linear function of the LOLIMOT submodel, although weighted by the $\sigma$ function, approximates the source data with a higher value of the mean square deviation. The consequence of this scenario is the partitioning of the LOLIMOT submodel, which enables a more flexible approximation, i.e. an approximation that will better accompany the observed data. Also, Figure 6 shows the iso-contour of the condition function that delimits the IC engine global operation space according to a predefined ratio of 30\%:70\%.

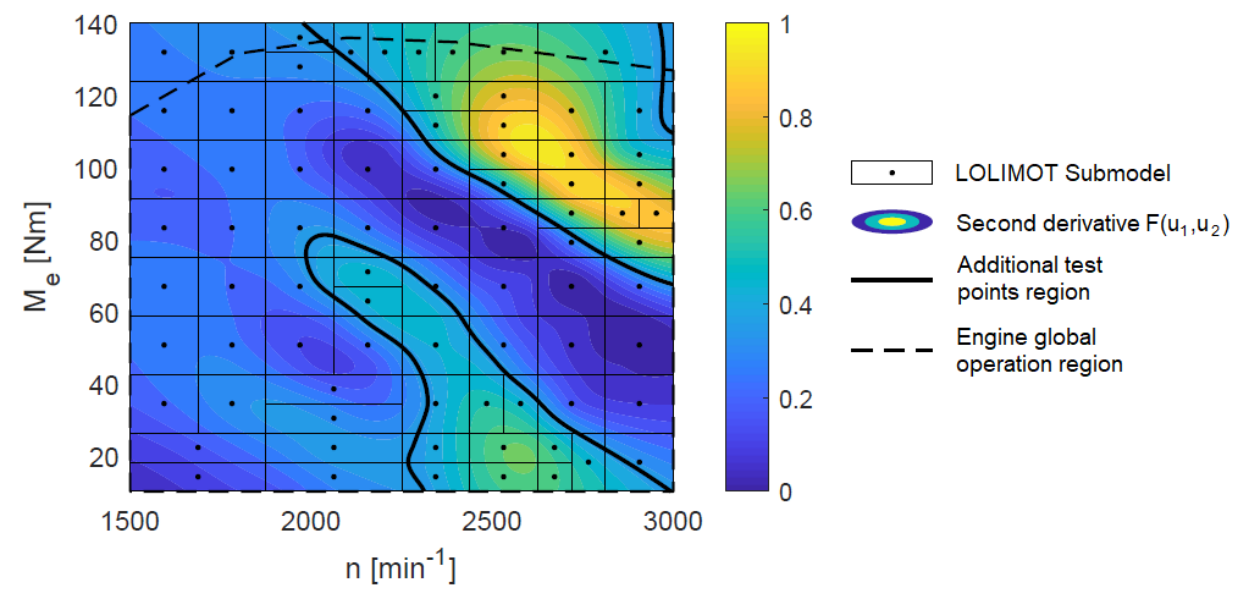

Figure 6 Quantification of the area for adding test points, the position of the LOLIMOT approximation submodels and dividing boundary of higher and lower test points population based on $P \_21$ parameter

The shown share of the IC engine operating domain is empirically determined as a compromise between the minimum allowable distance between design points, the number of starting points and the points added to the test plan for a given dimension of the input domain. Equation 4 is given in the index notation and thus allows determination of condition function in n-dimensional space, which for higher dimensionality of the global operation space means defining hyper-space to add test-plan points. The processed nonlinearity, i.e. the required IC engine universal characteristic, is unknown at the moment of the design of experiment, and the usage of SDS testing methodology as a way of collecting knowledge about the system under test can contribute in that sense. The results of the SDS tests cannot replace the stationary obtained data, but they can approximate the shape of nonlinearity and indicate areas within which it would be desirable to increase the number stationary test plan points. In contrary, this method can also indicate regions of insignificant experiment configuration, which leads to test plan reduction and thus to experimentation efficiency improvement. By analysing data of intake manifold pressure, obtained using SDS test methods, the areas for adding significant points into stationary test plan, are shown in the Figure 7. The measuring chain used for $\mathrm{P} \_21$ pressure readings, is characterized by a relatively fast response, so positions of the calculated areas are similar to that obtained by the stationary testing results. It is noticed that the approximation determined on the basis of 
the SDS test with the slowest control parameter rate of change (the longest test marked as D600) has a relatively good match with reference stationary results analysis. Test marked as D120, is characterized by the fastest execution, and slight mismatch with reference data is noticeable, but still, there is great coincidence to stationary data in general.

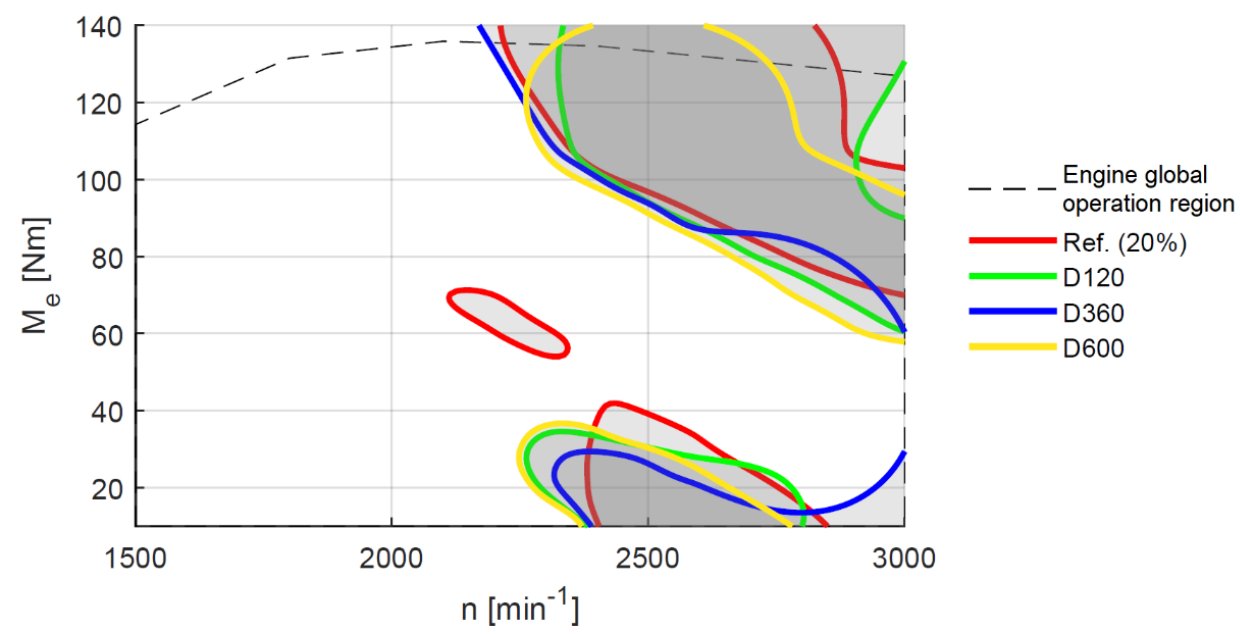

Figure 7 Areas for adding most significant test points based on reference stationary tests results and based on SDS tests of different durations for the P_21 output parameter

\section{CONCLUSIONS}

IC engine testing, using the SDS methodology, has the best results if the observed output parameter is characterized by a relatively short settling time, i.e. fast dynamic response. It is found that this category includes pressure and flow measurements in the time domain, as well as engine cylinder pressure indication. Also, it can be stated that certain temperature measurements can give acceptable SDS approximations if the measured temperature amplitude, during SDS sweep, is relatively narrow. In contrast, measuring the exhaust gas temperature of the IC engine, at the sections in front of and behind the turbine, in dynamic conditions, gives results that deviate significantly from stationary results, but these data could be used for further stationary test plan optimisation, such as optimizing of the stationary test plan execution order.

\section{REFERENCES}

[1] Wiartalla, A.: "FEV study examines drivetrain topologies in 2030 - FEV," FEV Group GmbH, Aachen, Germany, Jul. 2017. Accessed: Apr. 23, 2019. [Online]. Available: http://magazine.fev.com/en/fev-study-examines-drivetrain-topologies-in-2030-2/.

[2] Krause, J., Thiel, C., Tsokolis, D., Samaras, Z., Rota, C., Ward, A., Prenninger, P., Coosemans, T., NeugebauerS., Verhoeve, W.: "EU road vehicle energy consumption and CO2 emissions by 2050 - Expert-based scenarios", Energy Policy, 2020, Vol. 138, p. 111224, Doi: 10.1016/j.enpol.2019.111224.

[3] Isermann, R.: "Engine Modeling and Control", Berlin, Heidelberg: Springer Berlin Heidelberg, 2014. 
[4] Berger, B.: "Modeling and Optimization for Stationary Base Engine Calibration," Technische Universität München, Munich, Germany, 2012.

[5] Tietze, N.: "Model-based Calibration of Engine Control Units Using Gaussian Process Regression”, PhD Thesis, Technische Universität, Darmstadt, 2015.

[6] Godburn, J., Brown, D., Case, R.: “Computer-controlled non-steady-state engine testing", International Journal of Vehicle Design, Vol. 12, No. 1, 1991, pp. 50-60. Doi: 10.1504/IJVD.1991.061671.

[7] Ward, M.C., Brace, C.J., Vaughan, N.D., Ceen, R., Hale, T., Kennedy, G.: "Investigation of 'Sweep' Mapping Approach on Engine Testbed", 2002. Doi: 10.4271/2002-01-0615.

[8] Keuth, N., Thomas, M., Pflügl, H., Martini, E., Bergold, S.: "Utilization of the Slow Dynamic Slope Methodology for the Calibration of the ECU-Functions "Air Charge Determination' and 'Torque Prediction' in the Series Production," in Design of Experiments (DoE) in Engine Development: modern development methods to meet new challenges, Berlin, Germany, 2009, Vol. 1, pp. 122-136, [Online]. Available: http://d-nb.info/992518733.

[9] Leithgöb, R., Bollig, M., Büchel M., Henzinger F.: "Methodology for efficient calibration of model based ECU structures," Wiesbaden, 2005, pp. 195-210.

[10] Murakami, Y.: "Slow Dynamic Slopes (SDS) Methodology Applied for a Stratified Gasoline Engine," in Design of Experiments in Engine Development III, Renningen, Germany, 2007, pp. 413-423. [Online]. Available: http://d-nb.info/984171886.

[11] Mancini, G.: “Automotive Diesel Engine Transient Operation: Modeling, Optimization and Control," PhD Thesis, Università di Bologna, Bologna, 2014.

[12] Shimojo, K., Kitamura, Y., Sato, M., Adachi, S.: "Soot Modeling Using QuasiStationary Measurement for Gasoline Engine", Transactions of Society of Automotive Engineers of Japan, 2016, Vol. 47, No. 3, pp. 665-671. Doi: $\underline{10.11351 / \text { jsaeronbun.47.665. }}$.

[13] Miljić, N., Popović, S., Kitanović, M., Mrđa, P., Đinić, S., Petrović, V.: "Benchmarking of an existing engine in an automated way", AVL, Graz, Austria, ICED 1510/C01 SDS, Nov. 2015.

[14] Miljić, N., Popović, S., Mrđa, P., Kitanović, M. : "Slow Dynamic Slope method in IC engine benchmarking”, Thermal Science, 2018, Vol. 22, No. 3, pp. 1271-1283. Doi: 10.2298/TSCI170921226M.

[15] Mrđa, P., Miljić, N., Popović, S., Kitanović, M.: “Continuous slow dynamic slope approach for stationary base internal combustion engine mapping", Thermal Science, 2020, Vol. 24, No. 1, pp. 147-158. Doi: 10.2298/TSCI190308171M.

[16] AVL List GmbH, “AVL CAMEO 4." AVL LIST GmbH Graz, 2018, [Online]. Available: https://www.avl.com/-/avl-cameo-4-.

[17] Nelles, O.: "Nonlinear System Identification, From Classical Approaches to Neural Networks and Fuzzy Models", Berlin, Heidelberg: Springer Berlin Heidelberg, 2001.

[18] Collette, Y.: "Planification d'expériences," Renault - Direction de la Recherche, 2006, [Online]. Available: http://ycollette.free.fr/Tools/Papers/Cours/01_Model_V3.pdf. 